\title{
OPEN LEARNING: KEY FOUNDATIONS OF PERSONAL LEARNING ENVIRONMENT
}

\author{
Abdullah Alenezi \\ Northern Borders University, Arar, Saudi Arabia
}

\begin{abstract}
The concept of open education is one of the concepts that have taken a clear place on the academic map of higher education in many countries of the world. This type of education has become an important resource for universities to overcome many of the material and academic problems. The aim of this study is to analyse the role of open learning as the key foundations of personal learning environment. The interview respondents were nine teachers who are currently working with different open learning programs in Saudi Arabia. The nine teachers were from three different institutes in Saudi Arabia. It was identified through the interviews that the emergence of Open Textbooks, which is part of the broader movement known as Open Learning Resources, can help meet these challenges and improve the quality of the learning process. Higher textbooks for higher education students, especially middle school students, In the beginning of the last decade in the Saudi Arabia, to what is known as the "crisis of the textbook" and tried to solve many solutions to address the problem, such as the rental of the book to the student and the adoption of e-book and others, but the most prominent solutions are effective and impact, the emergence of non-profit organizations in cooperation.
\end{abstract}

\section{KEYWORDS}

Open learning, Saudi Arabia, e-learning

\section{INTRODUCTION}

Since the end of the last century, technology has taken on a leading role in the development of societies. One of the main triggers of this technological spread has been its adaptation to the different scenarios of human activity. The progress of technologies and their impact on the behaviour of societies has forced them to seek the most appropriate means to get the best use of them and reach the greatest number of people (Attwell, 2007, Wilson, 2008, Salinas, 2009c, Couros, 2010).

Among the main challenges facing the education systems of the Saudi Arabia, according to the Commission of 31 January 2001, the risk of social exclusion stands out if the principle of equality of opportunity were not adequately addressed. Knowledge-based societies could open a considerable gap between those who had access to Information Technology and those who did not. In addition, referred to as the OECD isDeSeCo Project (1997), among its universal competences on economics, culture, and values (TORIBIO, 2010).

The common idea of a digital educational resource is educational content in web format such as text and images, but this term also includes documents with guidelines on how to teach a certain subject or even data sets on evaluation and functioning of educational experiences, among others (SICILY, 2007). 
International Journal on Web Service Computing (IJWSC), Vol.10, No.1/2/3, September 2019

From education, strategies for the introduction of digital technologies are carried out, which means adapting the didactic procedures implemented with analogue technologies. This adaptation is transversal and involves all levels.

The features that distinguish digital technologies from their precedents are based on the logic of interactivity, both the user with the devices and the users with each other.

The technological tools, on the other hand, also undergo processes of adaptation according to the models of prevailing social relations. For authors such as Cabero (2003), the coverage of collaborative and cooperative learning is understood as a resource, a strategy, and methodology of instruction, in which traditional roles played by the teacher and the student in a traditional methodology of transmitter and Receiver of the information, and is transferred to new environments where the knowledge is developed jointly and collaboratively.

\section{RESEARCH AIM}

The aim of this study is to analyse the role of open learning as the key foundations of personal learning environment

\section{Rationale}

The basis of the concept depends on the conception of Personal Learning Environment -PLE, in the English sense. If we accept that the PLEs are located within the limits of the new spaces of educational communication (public communication vs. private communication, institutional environments, social environments or personal environments, etc.) it is clear that both the definition of the concept and its foundations require discussion and reflection (Coffey 1977, Lewis 1985, Lewis and Spencer 1986, Boot and Hodgson 1987). It can be established that one of its bases, perhaps the most solid from the pedagogical perspective, are concepts such as flexible education and open learning. From the moment we talk about adult education, with autonomous consciousness and that exercise in relation to their learning, the development of PLE falls within what is understood as open learning or flexible education: the user has choice, is free to Maneuver, you have control over how you learn. We are, therefore, faced with processes centred on the student, which have traditionally been contemplated in Didactics. Another thing is that they have been scarcely practiced (Casquero et al., 2008, 2010, Santos and Pedro, 2010, White and Davis, 2011, Salinas, 2009b, Salinas, Marin and Escandell, 2011).

\section{THEORETICAL FRAMEWORK}

Open learning: towards a better understanding of the PLE

We can consider open learning as a pioneering approach in the current of eliminating barriers to adult learning and the consideration of independence and autonomy in the learning process. For Coffey (1977), open learning refers to the removal of administrative and educational barriers to learning. A NBEET report (1992) defines open learning as a form of study in which a student can enter without prior preparation, where he has the greatest flexibility in the choice of study subjects, the period, place and time of study, And in the modes of evaluation.

Both definitions of open learning focus on the expansion of the educational offer by eliminating institutional barriers. Lewis and Spencer (1986) go on to point out as one of the most important aspects of open learning the commitment to help students acquire independence and autonomy in learning. It has been customary to find partners in the concept of open learning and distance 
learning, since it connects with some approaches or currents of thought about distance education, especially with theories of autonomy and independence (Keegan, 1986). One of its representatives, Wedemeyer (1971), is based on a social-democratic ideal and a liberal educational philosophy, on equal opportunities to access education, overcoming geographical, economic, social limitations, etc.

Moore $(1983,1991)$, On the other hand, relies on the relation between personal autonomy and geographic distance, while Holmberg (1985) emphasizes the interaction. The student is seen as an autonomous person who is spatially and temporally separated from the teacher, but with whom he interacts through technology-mediated communication systems. Undoubtedly, open learning can be done remotely, but it can also be done in a crowded reading room or in the classroom, it can happen whether the student belongs to a group or is learning at his own pace.

\section{A. Administrative Determinants}

Administrative determinants to which the student must attend: teach attendance at a predetermined place, time and number of sessions, in-group by the teacher, the rules of the organization. It refers, therefore, to the provision of freedom, or better of optionality, to students in access, admission, course selection, and freedom in temporal and spatial determinants. In this sense, these characteristics would not require particular educational requirements and provide accessible guidance and instructional support systems for the student. Kember (1995), for his part, suggests that this dimension of open learning has developed due to social and political pressures by removing the barriers that prevent participation in adult education.

\section{B. Teaching Determinants}

The other dimension of the concept of open learning is related to the translation of the didactic determinants: highly adjusted specified learning goals; Sequence of teaching and place; The strategy to teach the individual teacher or the organization. Failure to apply such determinants drifts towards closed educational designs. It refers to an educational model or student-centred philosophy versus that of institution-centred or teacher-centred (Cunningham, 1987; Kember, 1995). Paul (1990) proposes a series of dimensions that would come to express with respect to what and to what degree an institution can be considered open and that represents both dimensions well (Table. 1)

Table1. Openness dimensions of an institution (elaborated from Paul, 1990).

\begin{tabular}{|l|l|l|}
\hline \multirow{5}{*}{$\begin{array}{l}\text { ADMINISTRATIVE } \\
\text { DETERINANTS }\end{array}$} & Accessibility & $\begin{array}{l}\text { Previous academic credentials } \\
\text { Weather } \\
\text { Physical location } \\
\text { Financial Determinants } \\
\text { Personal characteristics } \\
\text { Social responsibility }\end{array}$ \\
\cline { 2 - 3 } & Flexibility & $\begin{array}{l}\text { Frequency in periods of } \\
\text { admission } \\
\text { Learning pace } \\
\text { Optional Support Services }\end{array}$ \\
\hline & & \\
\cline { 2 - 3 } & Student's control over content and structure \\
\cline { 2 - 3 } & Choice of distribution system \\
\cline { 2 - 3 } & Accreditation \\
\hline \multirow{5}{*}{ TEACHING } & Very specific learning goals \\
\cline { 2 - 3 } & Sequence of teaching and place \\
\hline
\end{tabular}


International Journal on Web Service Computing (IJWSC), Vol.10, No.1/2/3, September 2019

\begin{tabular}{|l|l|}
\hline DETERMINANTS & Teacher's didactic strategy \\
\cline { 2 - 2 } & Didactic strategy of the organization \\
\hline
\end{tabular}

It should be considered that what we understand as open learning is the natural way in which much learning has occurred over time (Race, 1994). It is like saying that learning is something we do for ourselves, even when we learn from others, and this largely coincides with the most characteristic aspects of the PLE, which would become somewhat configured to make the best use of our way Natural way of learning things, in this case exploiting the possibilities of ICT. Since the PLEs are different systems that help students take control of their own learning, i.e., decide their own learning objectives, manage their own learning (both content and process), Communicating with others in the learning process, and everything that contributes to the achievement of the objectives align with the basic principles that have inspired from the beginning to open learning.

\section{The PLE From The Perspectives Of Open Learning And Flexible Education}

The PLE concept is becoming an important reference in Educational Technology, since it is gaining widespread recognition of its pedagogical value, as well as its framework and its components. In this sense, it can be associated, as it were said, with a whole stream of models and conceptions that refer to student-centred learning processes.

Unlike traditional virtual teaching-learning environments that focus on the institution or a course, the personal learning environments are focused on the user, who has the possibility of creating and consuming information and knowledge.

Alongside this feature, it has been considered as another key element in the PLE connection open learning / flexible education, the integration of formal, non-formal, and informal learning. Both aspects are considered key in the evolution of learning scenarios and should be considered in the processes of reflection, research, and innovation with a future perspective. The advances in the reflection and research about the PLE find, in approaches associated with open learning, basic elements. Based on these two premises, present in the conceptions of open learning and flexible education, we can consider in the foundation that both contribute to the reflection and development of the PLE, four essential characteristics that are present in all the tendencies associated with open learning and (Van der Brade, 1993; Moran and Myrlinger, 1999).

Personal learning environments respond to these characteristics. They are supported for this in the systems and software applications that constitute the so-called social software, or Web 2.0, whose evolution advances parallel to the movements that are making the Internet de facto become the communicative area par excellence. Obviously, this dynamic causes conceptual changes and, above all, the appearance of new terminology, but as far as didactic foundations on which they are based, surely it will be possible to continue finding references in the streams of open learning, flexible education and Trends that have derived from them.

It can contribute to look at the PLE from this pedagogical perspective, the proposal of two models of open learning that do Boot and Hodgson (1987), which still not being exclusive, strongly determine the configuration of the training system and consequently the components of it. Based on the pedagogical principles that differentiate the 'administratively' programs from the 'open' educational ones, they point to two orientations: one takes a dissemination orientation (in practice, it offers administratively open learning) and another takes a developmental orientation More educational). 
From a pedagogical perspective, PLEs can be clearly associated with what Boot and Hodgson (1987) call developmental model, since it is oriented to the complete development of the person (especially the continued ability to search for the sense of self and the world That surrounds it) (Table. 2). Here the authors consider the three main elements of PLE: tools, resources and people.

Table 2. Open learning models (from Boot and Hodgson, 1987).

\begin{tabular}{|c|c|c|}
\hline CONCEPTIONS & DISSEMINATION & DEVELOPMENT \\
\hline Knowledge & $\begin{array}{l}\text { Something objective } \\
\text { (valuable commodity that } \\
\text { exists independently of the } \\
\text { people). } \\
\text { It can be stored and } \\
\text { transmitted. Epistemology } \\
\text { of objectivism. }\end{array}$ & 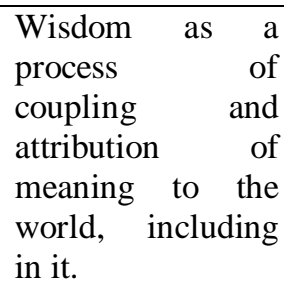 \\
\hline The & $\begin{array}{l}\text { Acquisition and addition of } \\
\text { facts, concepts and skills }\end{array}$ & $\begin{array}{l}\text { Epistemology of } \\
\text { relativity }\end{array}$ \\
\hline $\begin{array}{l}\text { Purpose } \\
\text { education }\end{array}$ & $\begin{array}{l}\text { Dissemination of stored } \\
\text { knowledge }\end{array}$ & $\begin{array}{l}\text { Elaboration and } \\
\text { processes of } \\
\text { meaning creation. }\end{array}$ \\
\hline $\begin{array}{l}\text { Meaning of } \\
\text { independence }\end{array}$ & Individualization & $\begin{array}{l}\text { Emphasis } \\
\text { personal } \\
\text { competence. }\end{array}$ \\
\hline $\begin{array}{l}\text { Bases of the } \\
\text { student's options }\end{array}$ & $\begin{array}{l}\text { Selection in a closed range } \\
\text { of options }\end{array}$ & $\begin{array}{l}\text { Global } \\
\text { development } \\
\text { the person }\end{array}$ \\
\hline
\end{tabular}

Open learning, in the perspective of development, allows students to define their learning and personal development needs through a process of negotiation, collaboration and cooperation.

In relation to the personal learning network, they emphasize the importance of people other than teachers as an inherent part of the learning process, providing challenges and collaboration in the construction of personal meaning and, in addition, their participation in the assessment as part of the process of Learning, understood as realized collaboratively in relation to shared common criteria. They identify the idea that the role of the tutor in a development orientation is a facilitator, personal resource, and co-learner. While the dissemination model would be associated with products (contents, materials, teaching packages, where knowledge can be seen as a valuable commodity that exists independently of people and as such, can be saved and transmitted (sold); Development would be associated with the learning process itself and the achievement of the learning objectives of adults. This feature makes open learning associated with development orientation as opposed to conventional distance learning that would be product oriented.

To attend to the teaching-learning model that underlies, and this requires a new look on the pedagogical models, a strong support of technologies, important changes in the organization as much administrative as of the materials and systems of communication and mediation (Salinas, $2004 b ; 2009 c)$. And they can be found from models that describe teaching as a technical process and that sees the teacher as a simple executor who has to equip the skills and abilities to increase their effectiveness through resources (deploying what has been termed 'Generic' methodologies), to more open models that see teaching as a space of knowledge and knowledge and sociopolitical space in which knowledge is selected, legitimized and distributed to subjects differently and sees the teacher as a professional with capacity Of decision and judgment and able to 
International Journal on Web Service Computing (IJWSC), Vol.10, No.1/2/3, September 2019

reconstruct his own practice critically and to include means in a creative way ('specific' methodologies).

\section{Methodology}

Qualitative research

The conduct of qualitative research, points out that knowledge is the result of interaction between the individual and his environment, so its purpose is to come to represent and interpret the culture as seen by the participants of the same (Sieburth, 1993, cited by García, 2006). This study used qualitative methodology as it has the main objective of description of the qualities of a phenomenon.

The work carried out based on this type of research, adopted a descriptive, interpretive, descriptive character because we were interested to indicate what really happens with the teachers of mathematics in their classrooms, and interpretative because, in addition to saying what happens we consider that it was necessary to analyse and understand the educational reality that could not be directly observed.

\section{Research Philosophy: Ethnography}

To understand more about this type of methodology used in this research, in Woods (1986) cited in Garcia (2006), the term ethnography derives from anthropology and literally means description of the way of life of a race or group of individuals.

\section{Information collection}

In the ethnographic research, the information sought is the one that has the most relationship and helps to discover the significant structures that give reason for the behaviour of the subjects under study. As this research is based on ethnographic philosophy, for this reason, the following types of information may be very relevant and has been used in completion of this research:

The content and form of verbal interaction between subjects

The interview: allows complementing and verifying the information obtained through participant and non-participant observation. The purpose of the interview is to reconstruct what happens in the study environment. Through the interview, you can reach a contact with individuals, creating certain conditions that allow participants to freely say what they think and feel, using their own language that is part of their natural reality. The interview can be casual and informal, or structured. Data collected through the interview can be recorded in the form of notes during or after completion of the interview, or it is also possible to use audio or video recording.

Elaboration of information records: In this stage, if there is videotaped material, it is transcribed directly and integrated with the field notes, to form the research records.

\section{Participants}

The interview respondents were nine teachers who are currently working with different open learning programs in Saudi Arabia. The nine teachers were from three different institutes in Saudi Arabia. The interviews were conducted via Skype and were transcribed based on the aim of this study. For privacy reasons respondents are referred as respondent 1, respondent 2 and respondent 3 etc in the analysis. 
Analysis and interpretation of results

Interpreting information is one of the key moments of ethnographic research, and involves a reflexive process through the review, of the information collected, with the purpose of discovering the meaning of each event or situation since the point of view of the participants. The interpretation phase starts from the strictly descriptive until arriving at the explanation of the situation approached.

\section{Confidentiality and Ethics}

All the information that is collected during the course of the research will be kept strictly confidential. The participants will not be identified in any reports or publications. Furthermore there are is no conflict of interest in conducting this research.

\section{RESUlTS AND DiscUSSION}

Among the technological and economic factors, it identifies the reduction of costs of infrastructure, hardware, and software, as well as a friendlier interface of the technologies of the information. On the other hand, he points out that it is easier and cheaper to produce content that, when shared, tends to reduce costs even more. New economic models are emerging for the distribution of free content.

"Materials under a Creative Commons license are transferred to users for use, reuse, translation, and adaptation to other contexts. Users undertake to use them for non-commercial purposes, to recognize the Institution that originally published it or the author, if applicable, and that the resulting material after its use is free again and can be used again by third parties. Among other legal aspects highlights the relationship between the teacher and the University," said respondent 1 when asked to comment on the legal aspects of Open learning programs.

The author grants rights of use, assumes intellectual property, and respects the conditions of use established by the owners. "The University where I work at, assumes the use of its site according to principles of respect to the author and his work. The growing willingness to share with third parties is one of the most noteworthy social factors,"said respondent 2.

Taking into account political aspects, the study indicates several reasons why governments may be interested in supporting such projects. "On the one hand, they facilitate access to learning materials for society as a whole, and in particular for groups of non-traditional students, allowing a greater proportion of citizens accessing education and more specifically higher education. On the other hand, it is an efficient way of promoting lifelong learning, narrowing the gap between formal and non-formal education and self-learning," said respondent 3 commenting on the political aspect.

Incentives such as the altruistic motivation to share their knowledge, non-monetary reward, for example through publicity and recognition among members of the open community, or for economic and commercial reasons, are perceived as a way for teachers and researchers. To become known more quickly in the market.

Respondent 4 while defining open education said, "A broad definition of open educational resources could include, in addition to didactic content and licenses under which such content is published, distribution tools, such as content management platforms or e-learning platforms." 
However, the study points out that open educational resources are open and free digital materials for educators, students and self-educators who can use and reuse for teaching, learning, and research $(\mathrm{OECD}, 2007)$. This is the big difference with other educational resources that are offered on the net.

Another of the actions carried out by UNESCO in promoting technologies in education is the sixth Education for All (EFA) Monitoring Report (2008). This report analyses the evolution of the commitment of 164 governments and organizations around the world to increase the educational opportunities offered to children, young people, and adults around the world by 2015 .

Some of the measures taken at the international level to improve learning through technologies are those of South Africa and India, which emphasize the importance of promoting ICT in education through SchoolNet, enabling the creation of school networks to improve Teaching and learning through collaboration and sharing of information.

In Saudi Arabia, the promotion of ICT in education through QSience, which installs laboratories in schools and establishes regional centres of education technologies for training and assistance, is intended. The use of ICT in the context of the modernization of education program is also mentioned in other Middle Eastern countries.

Saudi Arabia emphasizes the need to create a comprehensive ICT policy in education within the framework of national development policy. Professional development programs for teachers using ICTs, such as the project to strengthen digital education, are mainly developed in Egypt. Morocco refers to the need to carry out projects aimed at extending the use of ICT in education, focusing mainly on equipment, training and educational content. These provisions reflect the measures taken by other countries in ICT education. In developing countries, more emphasis is required on OER to reach a larger population (FARRELL and WACHHOLZ, 2003).

"The recent expansion of technologies and open learning has led to the development of two trends in education, greater use of different models of distance learning, termed open learning and the implementation of a series of pedagogical innovations related to ICT , used by both teachers and students," said respondent 5 .

In the Arab countries, the challenges of providing education, especially the higher ones, are higher than those faced by developed countries. All international and regional reports indicate a serious setback in the development of education as indicators of higher education are low in most Arab countries.

The greatest challenge facing higher education officials in the Arab countries is the huge numbers that will be included in the coming years. For example, according to respondent 6, "The age groups (1-14), 16-24 years, $45 \%$ and $21 \%$ of the total population respectively, which means doubling the demand for secondary and higher education in the near future." This necessitates the need to raise higher education enrolment rates, which are currently low in most Arab countries, ranging from $4 \%$ to $30 \%$ at best, to be $50 \%$ to $60 \%$, making the situation in Arab countries more difficult.

The quality of education and the adoption of traditional systems at all stages of education and reliance on the method of conservation and education and distance from the practical application and the use of modern education techniques to facilitate the understanding of information and turn it into reality, as confirmed by the International Development Bank in its latest report on the state of education in the Middle East and North Africa. 
"Despite the gloomy picture of education in the Arab countries, mentioned in the international reports, there are still rare opportunities to upgrade education, improve its quality, absorb additional numbers of students and reduce the cost of production in the educational process without the need for high financial investments," added respondent 6. (Openness) of the global educational resources on the Internet (Internet) is a real opportunity to meet these challenges and overcome those difficulties, where there are currently hundreds of university sites and educational institutions containing thousands of educational resources, such as: (Curriculum).

In the context of globalization and the transition to a knowledge economy, there has been a need in developed countries to increase enrollment rates, especially higher education, in addition to the need to rehabilitate the workforce in order to develop their skills in line with the new characteristics of professions that led to the development of the skills required for their performance within the structure of the knowledge society. "In order to meet the requirements of the development of education in accordance with the new reality, it faces a number of challenges, the most important of which is the high cost, which includes various elements", said respondent 6 , while adding, "The most important of which is the production of educational content such as textbooks, which is an obstacle to the enrollment of large segments of society in education, especially the higher and the middle. The United States is estimated to have more than 200,000 students per year."

Addressing the growing demand for education through traditional methods by expanding infrastructure, building new educational institutions and using traditional teaching methods is not possible; it requires large budgets that are difficult to provide, and it takes a lot of time and effort. Low effectiveness and unsuitable for qualifying students to meet the requirements of life in the third millennium.

"The OER movement has great potential for learning. The value of education is easy to use when they are encoded and numbered, which facilitates the partnership of educational institutions. Open learning resources (OERs) are other educational resources subject to a proprietary licensing and protection system, which makes it easier to use and adapt them without permission from the author of the title", said respondent 7.

It is important to recognize that open educational resources are not an adjunct to e-learning, but that the use of OER can be done without an Internet service. The concept of open education resources also differs from the concept of "open education", which requires a systematic analysis of the student's assessment process and needs administrative accreditation and support systems, among other things.

The challenges facing the textbooks can be divided into two parts. The first relates to the book itself, and the second relates to the user of the textbook, whether the student or the teacher. It is rare to find the appropriate book to cover all the subjects required in the course, and to provide it may not be the required depth. "Often content is not compatible with the context and characteristics of the local environment, especially in higher education, because most textbooks in Arab universities in general and Gulf universities in particular are foreign books, also require accelerated technology transformations and transformation," said respondent 8 .

"This is difficult to achieve except through a new book, in addition to the previous challenges, the challenge of high prices of books on the global level, especially for students of higher education, which is a huge financial burden on the budgets of higher education, especially in Arab countries because of Adopting English as a language of instruction in its higher education institutions", respondent 8 added. 
"As for the student, who is described as a digital student, who has spent thousands of hours sending and receiving e-mails, instant text, thousands of hours using a computer researcher, a rookie and a reader, and has listened to thousands of digital content when enrolled in higher education", said respondent 9.

The previous challenges have led some post-secondary education institutions to create the socalled course material prepared by the course teachers, leading to a clear variation in the output levels of these institutions, especially if they fall under one umbrella and adopt a single study plan for all of their colleges.

\section{CONCLUSION}

The trajectory of technology applied to the development of Open Educational Resources is influencing some theoretical principles on which socio-educational intervention is based. OERs are already a reality pursued by society. There are cases where the principles of these resources are used although the movement itself is unknown.

This article shows the programs and models at Saudi Arabia universities and international level that facilitate the penetration of the OER in the educational space. These resources in turn provide educational materials with benefit, facilitate communication, search for information, and promote access to education for people with physical, mental, or social disadvantages. They also allow obtaining other types of competences such as autonomous and cooperative work and creative and critical thinking.

\section{REFERENCES}

[1] Attwell, G. (2007). The Personal Learning Environments -the future of eLearning? En eLearning Papers. 2( 1)

[2] Boot,R. and Hodgson, V. (1987). Open learning: Mening and experience. EN Hodgson, V. Mann, S. Snell, R. (Eds.). Beyond distance teaching: Towards open learning. Buckingham: Open University press, pp. 5-15

[3] Coffey, J. (1977). Open learning oportunities for mature students. En Davies, C. (Ed.). Open Learning systems for mature students. CET Working Paper, 14.London : Council for Educational Technology.

[4] Casquero, O., Portillo, J., Ovelar, R., Benito, M. and Romo, J. (2010).iPLE Network: an integrated eLearning 2.0 architecture from a university's perspective. Interactive Learning Environments, 18(3), 293-308.

[5] Casquero, O., Portillo, R., Ovelar, R., Romo, J. and Benito, M. (2008).iGoogle and gadgets as a platform for integrating institutional and external services. Universidad del País Vasco. Workshop on Mash-Up Personal Learning Environments (MUPPLE’08).

[6] Couros, A. (2010). Developing Personal Learning Networks for Open and Social Learning. In Veletsianos, G. (Ed).Emerging Technologies in Distance Education. Edmonton: Athabasca University Press.

[7] Dirckinck-Holmfeld, L.; Hodgson, V. and McConnell, D. (Eds.) (2012). Exploring the Theory, Pedagogy and Practice of Networked Learning. New York: Springer.

[8] Duffy, T. M. and Cunningham, D. J. (1996). Constructivism: Implications for the design and delivery of instruction. In D. H. Jonassen (Ed.), Handbook of research for educational communications and technology. New York: Macmillan. 
International Journal on Web Service Computing (IJWSC), Vol.10, No.1/2/3, September 2019

[9] Holmberg, B. (1985). Distance education: Situation and perspectives. Buenos Aires: Kapelusz. Iiyosh

[10] Kumar, M. (eds.) (2008).Opening up Education.The Collective Advancement of Education through Open Technology, Open Content, and Open Knowledge. Cambridge, Mass: MIT Press

[11] Keegan, D. (1986). Foundations of Distance Education.London and New York: Routledge

[12] Kember,D. (1995). Open Learning.Courses for Adults. Englewood Cliffs NJ.: Educational Technology Pub.

[13] Lewis, R. (1986) What is Open Learning? Open Learning, 5(2), pp. 3-8.

[14] Lewis, R. and Spencer, D. (1986). What is open learning? Open Leaning Guide, vol. 4. Liber, O. (2005) Learning objects: conditions for viability,. Journal of Computer Assisted Learning 21(5). 366373

[15] Moore, M. G. (1983). «On a Theory of independent study», a Sewart, D.; Keegan, D.; Holmberg, B. (eds.). Distance Education: International Perspectives. London /New York.Manrtin's Press

[16] Moore, M. G. (1991). «Theory of distance education».Second American Symposium on Research in Distance Education.The University State University, University Park.

[17] Moran, L. and Myringer, B. (1999). Flexible learning and university change. En

[18] NBEET (1992) Changing Patterns of Teaching and Learning, Report 19, AGPS, Canberra.

[19] OCDE (2007).Giving Knowledge for Free: The Emergence of Open Educational Resources. Paris: OCDE

[20] Paul, R. H. (1990), Open Learning and Open Management: Leadership and Integrity in Distance Education. London :Kogan Page.

[21] Race,P. (1994). The Open Learning Handbook.London :Kogan Page.

[22] Salinas, J., Marín, V. and Escandell, C. (2011). A Case of an Institutional PLE: Integrating VLEs and E-Portfolios for Students. The PLE Conference 2011. Southampton, UK.

[23] Santos, C. and Pedro, L. (2010). What's the role for institutions in PLEs? The case of SAPO Campus.The PLE Conference 2010.

[24] Van den Brande, L. (1993). Flexible and Distance Learning.Chicherter (UK): John Wiley \& Sons.

[25] Wedemeyer, C. (1971). Independent Study.En L. Deighton (Ed.) Encyclopaedia of education, vol. 4. p. 548-57. New York: Macmillan.

[26] White, S. and Davis, H. C. (2011). Rich and personal revisited: translating ambitions for an institutional personal learning environment into a reality. The PLE Conference 2011. Southampton, UK

[27] Wilson, S. (2005). The VLE of the Future.En Wilson, S., Scott's Workblog, (January 17th, 2005).

[28] Wilson, S. (2008). Patterns of personal learning environments. Interactive Learning Environments, $16(1), 17-34$ 


\section{AUTHORS}

Abdullah Alenezi, Dr. of Education, is Assistant Professor in the Educational Technology Department, Faculty of Education, Northern Borders University, Saudi Arabia. His major areas of interest and expertise are: organizational change, teaching and learning outcomes arising from uses of leading-edge technologies, implementation and management of leading-edge technologies at the local authority and individual institution levels, uses and impacts of technologies and technology-based resources in formal educational

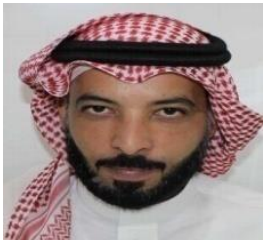
environments, distance learning and training, and technology integration in the Saudi context. 